\title{
Research the Causes of Surface Stains after Eloxal Coating for the Profile from the AlMgSi Alloy Using Substructural Analysis
}

Stefan Michna ${ }^{1}$, Natasa Naprstkova ${ }^{1}$, Dorota Klimecka-Tatar ${ }^{2}$

${ }^{1}$ Faculty of Production Technology and Management, J. E. Purkyne University in Usti nad Labem. Pasteurova 1, 40096 Usti nad Labem. Czech Republic. E-mail: michna@fvtm.ujep.cz, naprstkova@fvtm.ujep.cz

2Faculty of Management of Czestochowa University of Technology, ul. Armii Krajowej 19 B, 42-200 Czestochowa, Poland. E-mail: klimt@wip.pcz.pl

The aim of the research was to analyze the delivered profile samples, where appeared the darker spots with an irregular circular shape on the surface of light colored profiles after process of natural anodizing without colouration. Profiles are manufactured with alloy EN AW 6060 (AlMgSi) according to EN 573-3, which was carried out by heat treatment hardening. For material were performed measurements of Brinell and Vickers hardness, Vickers microhardness and substructural analysis in occurrence area of the dark spots and outside of these spots (light area of profile). Based on these analyzes it revealed significant difference of mechanical properties in these individual areas and different substructure of the solid solution $\alpha$ there. Based on knowledge of heat treatment technology is this substructure heterogeneity and diversity of mechanical properties (hardness and micro-hardness) of the given alloy caused by uneven localized cooling after solvent annealing in the hardening process. The occurrence of inhomogeneities is then right to express to different color profile to the surface after the anodizing process.

Keywords: alloy AlMgSi, substructural analysis, heat treatment, Brinell hardness, Vickers microhardness, solid solution $\alpha$

\section{Acknowledgement}

Authors are grateful for the support of grant SGS 2014 UJEP and of grant OP 2.2 No. CZ.1.07/2.2.00/28.0296.

\section{References}

[1] MODOLFO, L. F. (1979). Aluminium Alloys, Structure and Properties. Butterworths, London GB.

[2] MICHNA, S., LUKAC, I., OCENASEK, V., KORENY, R., DRAPALA, J., SCHNEIDER, H., MISKUFOV, A. a kol. (2005). Encyklopedie hliniku. Adin, Presov, ISBN 80-89041-88-4.

[3] NAPRSTKOVÁ, N. (2012). Vliv ockovani slitiny AlSi7Mg0,3 oCkovadlem AlTi5B1 na opotrebeni nastroje pri jejim obrabení. In Strojirenska technologie, Vol. 17, No. 5,6, p. 330-338.

[4] NAPRSTKOVÁ, N., KUSMIERCZAK, S., CAIS, J. (2013). Modification of AlSi7Mg0.3 alloy by strontium. In Manufacturing Technology. Vol. 13, No. 3, p. 373-380.

[5] KUSMIERCZAK, S., SVOBODOVA, J., BITTNER, M. (2011). Analýza prríčin vzniku zhoršené tvářitelnosti u slitiny typu AlMg. In Strojirenska technologie, Vol. 16, No. 4, p. 37-41.

[6] HURTAlOVA, L., TILlOVA, E., CHALUPOVA, M., BELAN, J., VASKO, A. (2014). Microstructure Control of Secondary A 231 Cast Alloy Used in Automotive Industry. In Manufacturing Technology. Vol. 14, No.3, p. 326-333.

[7] GRZINCIC, M., LUKAC, I. (2014). Identification of Intermetallic Phases in the Alloy AlSi6Cu4. In Manufacturing Technology, Vol. 14, No. 2, p. 160-166.

[8] ASM Handbook (1991). Vol.4, Heat Treating, ASM International, USA, ISBN 0-87170-379-3.

[9] BOLIBRUCHOVA, D., TILLOVA, E. (2005). Zlievárenské zliatiny Al-Si. ŽU v Žiline - EDIS, ISBN 80-8070485-6.

[10]WEISS, V. (2012). Prodloužení modifikačního účinku pomoci beryllia u slitin AlSi7Mg0,3. In Slévárenství, No.56.

[11]LUKAC, I., MICHNA, S. (2001). Colour Contrast, Strukture and Defects in Aluminium and Aluminium Alloys. GB, Cambridge international science publishing, ISBN 18 98326-70-3.

[12]VAJSOVA, V., MICHNA, S. (2010). Optimization of AlZn5,5Mg2,5Cu1,5 Alloy Homogenizing Annealing. In Metallofizika i Noveishie Teknologii, Vol. 32, No 7, pp. 949 - 959, ISSN 1024-1809. 
[13]MICHNA, S., NAPRSTKOVA, N. (2012). The use of fractography in the analysis of cracking after formed workpiece blank mechanical machining from the AlCuSnBi alloy. In Manufacturing Technology, Vol.12, No 13. ISSN $1213-2489$.

[14]SVOBODOVA, J., CAIS, J., MICHNA, S., BRUHA, M. (2013). Research of Corrosion Propertis of Al-Si Alloys Antimony Alloyed. In Manufacturing Technology, Vol. 13, No. 3. ISSN 1213-2489.

[15]MICHNA, S., KUSMIERCZAK, S. (2012). Prakticka metalografie. UJEP v Ústí nad Labem, 245 pp., ISBN 97880-7414-503-2.

[16]MICHNA, S., KUSMIERCZAK, S. (2008). Technologie a zpracování hliníkových materiálů. UJEP. Ústí nad Labem

[17] VAJSOVA, V. (2009). Structural inhomogeneity by Al-Cu alloys casting into metal and bentonic form. In Transactions of the Universities of Košice, No. 1, ISSN 1355-2334.

[18]NOVA, I., SOLFRONK, P., NOVAKOVÁ, I. (2011). Vliv mnozstvi dislokaci na tvaritelnost slitin hliniku. In Strojirenska technologie, Vol. 16, No. 2, p. 28-34, ISSN 1211-4162. 